\title{
THE ELECTRIC INTERURBAN RAILWAYS IN AMERICA
}

GEORGE W. HILTON and JOHN F. DUE

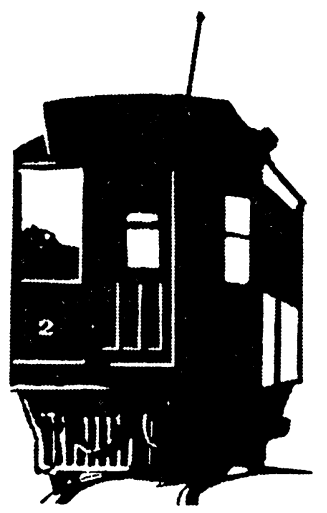

STANFORD UNIVERSITY PRESS

STANFORD, CALIFORNIA 
Stanford University Press

Stanford, California

(C) 1960 by the Board of Trustees of the

Leland Stanford Junior University

ISBN 0-8047-40I4-3

Original printing 1960

First paperback printing 2000

Last figure below indicates year of this printing:

$\begin{array}{llllllllll}20 & 19 & 18 & 17 & 16 & 15 & 14 & 13 & 12 & 11\end{array}$ 


\section{To \\ JAMES EDWARD DILLON COLEMAN \\ (1925-I944)}

who was killed in France in the Second World

War. He would have found in this book little that he did not know. 



\section{Preface}

T HE ELECTRIC interurban railway played a major but short-lived role in the development of intercity passenger transport. Basically, it provided a transitional step from almost sole reliance upon the steam railroad to an almost equally complete dependence on the automobile. Offering greater convenience and flexibility for short-distance travel than the railroad, the interurban greatly increased passenger mobility in the areas that it served, but it quickly gave way to the motor vehicle, which offered still greater flexibility. The interurban and the motor vehicle were first developed in roughly the same period; had the latter been perfected more rapidly, the interurban would have been killed in infancy. As it was, the interurban initially far outpaced its competitor, only to have the motor vehicle surpass and eventually destroy it. The intercity electric railway was a peculiarly American institution; although substantial mileage was built in parts of continental Europe, especially in the Low Countries and in Germany, only in the United States did a widespread network develop.

The interurbans have received much less attention than their significance in American economic history warrants. The Lynds' comprehensive studies of the society of Muncie, Indiana, are in a sense typical ; although Muncie was a major interurban junction, there is barely a mention of the interurban in Middletown and Middletown in Transition. Even general transportation histories have only incidental references to the interurbans, and local historians have ignored the industry almost entirely. To some extent, this neglect is compensated for by the publication of detailed histories of a number of interurbans by groups specifically interested in the technology and history of electric railways. Many of these studies are of high quality, and have preserved substantial amounts of detailed information which would otherwise have been lost. They are, however, almost purely descriptive, and they have never achieved a wide audience.

This general history of the interurbans was made possible in large measure by the availability of sets of the Electric Railway Journal and its predecessors, the principal trade journal of the street railway and interurban industries. The excellence and comprehensiveness of the Electric Railway Journal were mainly due to the high standards of its editor for many years, Henry W. Blake. An electrical engineer trained at Yale and MIT, Blake was an associate of Frank Sprague in the development of the electric streetcar. In 1891, Blake became associated with the Street Railway Journal, which in 1908 became the Electric Railway Journal. He was its editor until January 1, 1925, and remained associated with the magazine until his death in 1929. 
The authors are also greatly indebted to a number of authorities for their assistance. In particular, indebtedness is due Dr. Thomas Conway, Jr., sometime Professor of Finance in the Wharton School of the University of Pennsylvania, and successively President of the Chicago Aurora and Elgin, the Cincinnati and Lake Erie, and the Philadelphia and Western, for his suggestions and his kindness in reading a portion of the manuscript. The authors are also very grateful to George Krambles, Operations Planning Engineer of the Chicago Transit Authority, for his comments on the manuscript, discovery of a number of errors, and assistance in providing illustrations. Stephen D. Maguire, Electric Lines Editor of Railroad Magazine, read the manuscript and assisted in obtaining information. Dr. George T. Oborn, Vice-President of Illinois Wesleyan University, kindly made available to us extensive material he had compiled on the Indiana interurbans, and permitted us to use his data on these companies.

Other men who have been of particular assistance are Charles W. Hoke, President of Norwalk Truck Lines; Felix E. Reifschneider, who has long been active in electric railway historical circles; Professor J. W. Martin, Director of the University of Kentucky Bureau of Business Research; Professor R. W. Harbeson of the University of Illinois; Professor Robert L. Rivers of the University of Massachusetts; Professor Carl Shoup of Columbia University, whose father headed the Pacific Electric during its peak years ; Robert E. Lee of the Detroit Historical Commission ; Julian M. Bamberger of Salt Lake City; Professor Elvis L. Eckles of Alleghany College; Mr. Terence W. Cassady; and Mr. Philip T. Clark, Comptroller of Revenue of the Province of Ontario. A number of people provided information on individual interurbans, and we appreciate the courtesy of Trains magazine in making their library available to us. Several railroads, electric railways, bus lines, and power companies have provided information; these include the Western Pacific, the Southern Pacific, the Spokane Portland and Seattle, the Pennsylvania, the Illinois Terminal, the Altoona and Logan Valley, the Conestoga Transportation Company, the Chicago North Shore and Milwaukee, the Chicago South Shore and South Bend, the Salt Lake Garfield and Western, the Bamberger, the Detroit Toledo and Ironton, the Chesapeake and Ohio, the Soo Line, the Canadian Pacific, the Canadian National, the Ontario Northland, the Idaho Power Company, the Ohio Power Company, the Georgia Power Company, the Virginia Electric Power Company, the Central Louisiana Power Company. City librarians and secretaries of chambers of commerce in a number of communities were also of assistance.

The authors are grateful to Mrs. Linda Brownrigg of the Stanford University Press for her assistance.

Maps were drawn by Mr. James Bier of the Department of Geography of the University of Illinois. 
Articles based in part on the material from which this book has been prepared have appeared in the Bulletin of the Upper Canada Railway Society, No. 50 (1958), and in the Journal of Finance, XIV (1959).

The study was facilitated by grants from the University Research Board of the University of Illinois and from the faculty research fund of the Department of Economics of Stanford University.

In a work of this character, it is all but impossible to avoid errors and imprecisions. Accordingly, the authors have arranged to publish factual errors brought to their attention in Headlights, which is the closest remaining approximation to a trade journal for the interurbans (see p. 436). The authors are indebted to the Electric Railroaders' Association, publishers of Headlights, and to its editor John Baxter for agreeing to this arrangement.

George W. Hilton JohN F. DUE

Stanford University

University of Illinois

January 1960

\section{Preface to the Second Printing}

The interurbans were so nearly extinct by 1960 that little need be said to bring our book up to date. Of the four lines that remained in 1960, only the South Shore Line and the Philadelphia Suburban Transportation Company survive; the Long Beach line of the old Pacific Electric was discontinued in 1961, and the North Shore Line was abandoned in 1963. The transfer of equipment between companies was not quite ended, for the Philadelphia Suburban Transportation Company bought the North Shore Line's Electroliners.

Beyond noting these developments, we have corrected the errors brought to our attention since the first printing appeared. We are grateful to readers who pointed out errors to us.

Finally, on p. 426 we have added histories of three small lines which we feel deserve inclusion.

University of California, Los Angeles

G.W.H.

J.F.D.

University of Illinois

May 1964 
